\title{
Interações entre os Poderes Executivo e Legislativo no Processo Decisório: Avaliando Sucesso e Fracasso Presidencial*
}

\author{
Simone Diniz
}

\section{INTRODUÇÃO}

\begin{abstract}
Q omo avaliar sucesso e fracasso na aprovação de uma determinada agenda governamental? Responder a esta pergunta analisando o presidencialismo brasileiro é o principal objetivo deste artigo. Na literatura especializada, pode-se encontrar duas grandes vertentes analíticas tratando dessa temática. Uma é fortemente influenciada pela obra de Richard Neustadt (1960) intitulada Presidential Power: The Politics of Leadership, cuja ênfase recai sobre as habilidades pessoais daquele que ocupa a Presidência, a qual passarei a me referir como Perspectiva Centrada na Presidência. Outra favorece a análise das instituições e das estruturas políticas, aqui denominada de Perspectiva Centrada no Sistema Político (Cameron, 2000; Jones, 1994; Peterson, 1993).
\end{abstract}

\footnotetext{
* Este artigo foi elaborado a partir de minha tese de doutorado, Presidencialismo(s) e seus Efeitos no Processo Decisório, defendida na Universidade de São Paulo - USP, Departamento de Ciência Política, financiada pela Fundação de Amparo à Pesquisa do Estado de São Paulo - FAPESP, em 2005. Agradeço os comentários dos professores Eduardo Noronha, Argelina Figueiredo, Maria Hermínia Tavares de Almeida e Eduardo Marques. Um agradecimento especial ao meu orientador, Fernando Limongi, ao amigo Sidney Jard e ao parecerista da FAPESP os quais fizeram valiosos comentários e sugestões às primeiras versões deste artigo. Agradeço também a Fábio Kerche pelo fornecimento de alguns dados.
}

DADOS - Revista de Ciências Sociais, Rio de Janeiro, Vol. 48, n-1 1, 2005, pp. 333 a 369. 
Na primeira perspectiva, o foco é a Presidência, e o ocupante do cargo é a personificação do interesse nacional. Sucesso presidencial é, acima de tudo, decorrente das qualidades individuais do presidente. São elas que permitem a um determinado presidente ter mais sucesso que outro, influenciando também o tipo de agenda de políticas propostas e os meios pelos quais os objetivos do presidente são perseguidos (Peterson, 1993). A ênfase recai sobre a influência pessoal que o presidente pode exercer. No entanto, há o reconhecimento de que essa capacidade não é perfeita e tampouco suficiente para conseguir o que se quer, porque outros atores políticos também têm poder de influência. Por isso, a natureza da influência política envolve barganhas recíprocas e mútua dependência entre dois ou mais atores, embora um deles seja o presidente $^{1}$. Mas a capacidade de exercer influência política é, acima de tudo, uma questão de ação individual e de capacidade de persuasão. Nas palavras do próprio Neustadt, "poder presidencial é o poder de persuadir" - persuadir os outros atores políticos a fazer o que a Presidência deseja.

A assertiva de que sucesso presidencial depende das habilidades pessoais do ocupante do cargo tem conseqüências para a análise do processo decisório. A disputa entre Executivo e Legislativo é posta como uma luta para formular a agenda política e definir os objetivos do Estado. Destaca-se a prerrogativa formal de separação dos poderes entre o Executivo e Legislativo, a qual, por sua vez, estrutura e legitima o conflito entre os poderes. Os dois ramos do poder seriam inerentemente confrontacionistas, com interesses, perspectivas e objetivos contraditórios e às vezes irreconciliáveis. As relações entre os poderes são postas em termos de um jogo de soma-zero, no qual a ascendência de uma instituição vem às expensas da outra. Nesse jogo, em geral, prevalece a instituição presidencial, mas há momentos de reação do Congresso, o qual passa a assumir uma posição de instituição principal (idem).

O Legislativo é avaliado basicamente em duas únicas dimensões: se seus membros apóiam ou não as ações do presidente; ou se os interesses localizados representados pelos congressistas predominam sobre os nacionais. O Legislativo nunca é visto como uma instituição apropriada para apresentar soluções às grandes questões sociais ou econômicas (idem).

Essa abordagem não deixa de ter sua fundamentação no mundo real. Há épocas de intenso conflito institucional e a separação constitucio- 
nal entre os poderes pode favorecer uma possível confrontação. Mas isso não implica, necessariamente, que as relações entre os poderes serão sempre um jogo de soma-zero. Tomar as relações entre os poderes como tal também leva a subestimar o papel desempenhado pelo Congresso enquanto instituição representativa, produtora de políticas e supervisora das ações do Executivo (idem).

A Perspectiva Centrada no Sistema Político, por sua vez, sugere que a Presidência e o Congresso operam em uma arena (legislativa), cuja fronteira é circunscrita tanto pelo Congresso quanto pela Presidência. As duas instituições funcionariam de forma articulada, e o desempenho do presidente seria decorrente de um jogo estratégico, no qual o resultado legislativo final seria estruturado, em grande parte, pelas escolhas feitas pelo governo. Suas conseqüências seriam totalmente calibradas pela Presidência através de consultas ou períodos de julgamentos de reações antecipadas (idem:40) ${ }^{2}$.

Sendo assim, sucesso e fracasso não poderiam ser avaliados, por exemplo, tomando como base apenas o resultado do trâmite legislativo das proposições de interesse do Executivo. Isso porque o processo de consulta impulsionado pelo Executivo poderia gerar modificações na iniciativa legislativa presidencial, com o objetivo de facilitar a passagem do projeto. Ou ainda, de forma alternativa, não havendo consulta, os responsáveis pela elaboração da proposta presidencial poderiam fazer alterações substantivas, com o intuito de evitar problemas com o Congresso ou para compensar os efeitos de emendas bem-sucedidas antecipando a atuação da oposição. Modificações totalmente contrárias à verdadeira, embora não revelada preferência presidencial, poderiam ter sido introduzidas intencionalmente, descaracterizando tal predileção. Assim, tanto no processo de consulta quanto no de antecipação, a proposta enviada ao Congresso poderia não ser a preferência sincera do presidente.

Nessa perspectiva, ao invés da suposição de conflito entre instituições separadas constitucionalmente, há o reconhecimento de que elas fazem parte de um mesmo sistema e que, quando buscam uma interação direta, podem experimentar tanto o conflito quanto a cooperação dependendo da ocasião (idem:79).

O sucesso presidencial seria decorrente do processo de formação de coalizões, ponto crucial de toda política coletiva, e do uso de ações estratégicas por parte do presidente. A avaliação do desempenho presi- 
dencial centrada na linguagem de sucesso e fracasso não forneceria os instrumentos analíticos adequados porque não contemplariam as interações entre os poderes que levaram a Presidência e o Congresso, da inércia para a ação pactuada, de aclamação para rejeição.

Segundo essa interpretação, o processo legislativo não pode ser entendido com referência somente a um ramo do poder. Como o Congresso agirá sobre uma determinada proposta apresentada pelo Executivo, em um dado momento ou para um tema em particular, nunca é totalmente previsível (idem; Jones, 1994). Isso porque as ações presidenciais e as do Congresso são influenciadas por uma diversidade de fatores, institucionais, políticos, econômicos que estabelecem contextos específicos nos quais as decisões são concluídas.

As duas vertentes analíticas têm um ponto em comum: ambas reconhecem, ao menos implicitamente, que sucesso presidencial depende de algum mecanismo de barganha. Na perspectiva centrada nas habilidades pessoais, a barganha dá-se através da persuasão, e o sucesso depende da capacidade individual do presidente de conduzir bem esse processo.

Para a perspectiva institucional, o poder presidencial ou a capacidade para definir uma determinada política não é uma qualidade individual. Atributos pessoais podem ter alguma influência sobre o poder presidencial, mas esses operam dentro de limites específicos e de circunstâncias estratégicas. Compreender o poder presidencial significa atinar para os jogos estratégicos que os atores políticos jogam e, para isso, é necessário identificar os instrumentos de barganha que operacionalizam esse jogo (Peterson, 1993; Cameron, 2000).

O poder de veto presidencial, de acordo com Cameron (2000), cujo trabalho toma o caso norte-americano como referência, seria um desses instrumentos. O processo de formação da legislação através do uso do poder de veto ocorreria através da: 1) antecipação das possíveis ações presidenciais; 2 ) de ameaças de veto; e 3 ) dos próprios vetos (através da reconsideração da proposição legislativa). Kiewiet e McCubbins (1998 apud Cameron 2000) encontraram evidências de que o Congresso norte-americano realmente tenta evitar o veto, antecipando a ação do Executivo e, dessa forma, modifica o conteúdo dos projetos. A pesquisa desenvolvida por Cameron (2000), por sua vez, indica que, nos períodos de governo dividido, o uso do poder de veto ocorre freqüentemente, e as ameaças de vetar legislação, rotineiramente, levaram os 
presidentes a obterem concessões importantes nos projetos de seus interesses.

Tanto no trabalho de Peterson (1993) quanto no de Cameron (2000), a noção de "ação estratégica" é central na análise do desempenho do Poder Executivo. No entanto, a questão que se coloca é como avaliar esse desempenho?

Para avaliação do desempenho do Poder Executivo norte-americano, alguns analistas têm se dedicado a criar indicadores que representem a atuação da Presidência na produção legislativa. Um deles é elaborado a partir da contagem das votações nominais em matérias sobre as quais a Presidência toma posição. Esse índice, como observado por Jones (1994:193), gera alguns problemas para a avaliação do desempenho presidencial. Não leva em consideração, por exemplo, os projetos votados simbolicamente ou os rejeitados ou não apreciados nas comissões. Outro aspecto criticado pelo autor é o fato de muitas votações nominais recaírem sobre poucos temas. A análise da gestão de George Bush em 1989, por exemplo, indica que, de onze das quatorze vitórias atribuídas ao presidente, e oito das suas onze derrotadas, foram contabilizadas apenas em dois projetos.

\section{INTERAÇÕES ESTRATÉGICAS - COMO ANALISÁ-LAS A PARTIR DO PRESIDENCIALISMO BRASILEIRO?}

Nas últimas duas décadas, o debate sobre a eficácia governamental para a tomada de decisão e implementação de políticas, no Brasil, cindiu-se em duas grandes vertentes. De um lado, estão os que defendem que as relações entre os Poderes Executivo e Legislativo são conflituosas e que os governos apresentam baixos índices de eficácia na implementação de sua agenda (Shugart e Carey, 1992; Sartori, 1996; Mainwaring e Shugart, 1997; Lopes, 1996; Ames, 2003). De outro, estão os que argumentam que não haveria nenhum conflito estrutural de interesses insolúvel entre a Presidência e o Congresso e que o Executivo é um ator central na produção legislativa, com expressivas taxas de dominância e sucesso (Figueiredo e Limongi, 1999; Santos, 1997).

Críticos dos trabalhos de Figueiredo e Limongi tendem a ressaltar que o sucesso do Executivo estaria sobrevalorizado, em razão de os estudos empíricos não contemplarem as propostas que a Presidência teria interesse em aprovar e que não chegaram a ser transformadas em lei. Haveria uma agenda "não aprovada" que indicaria justamente o grau 
de conflito entre os poderes, não capturado pelas pesquisas dos autores (Ames, 2003). Postos nesses termos, a discussão sobre as relações entre os Poderes Executivo e Legislativo desloca-se para um aspecto ainda pouco explorado: a definição do que vem a ser a agenda governamental e quais seriam os melhores indicadores para o grau de sucesso ou fracasso do Executivo.

A avaliação do desempenho presidencial nos termos colocados por Peterson (1993) e Cameron (2000) introduz alguns aspectos fundamentais para a compreensão da ação dos presidentes enquanto produtores de políticas. A observação quanto à possível ocorrência de processos de "consulta" e de "antecipação de ações" alerta-nos para os limites de se tomar a apresentação formal de uma proposição como sendo a preferência sincera do presidente. No entanto, assumindo que a proposta apresentada contempla em alguma medida a preferência do Executivo, ainda assim permanece a questão de como avaliar sucesso ou fracasso presidencial.

Qual seria a verdadeira agenda legislativa do presidente? O programa de governo? As "intenções" do Executivo veiculadas na imprensa? As propostas que o Executivo envia para o Congresso? Se se define como agenda as propostas encaminhadas ao Congresso, as indicações do grau de sucesso ou fracasso da agenda do Executivo poderiam ser feitas através do cômputo dos projetos aprovados e dos arquivados. Mas dificuldades aparecem mesmo nessa operação aparentemente simples. Deve-se considerar como sucesso somente os projetos aprovados na íntegra, sem que qualquer alteração tenha sido feita ao projeto original? Os aprovados com emendas ou substitutivos - com variações que vão desde pequenas modificações até alterações radicais - devem ser computados como fracasso ou sucesso?

No caso de uma alteração substantiva que mude a vontade do presidente, este pode recorrer ao veto. Como se sabe, o Executivo pode se valer tanto do veto total quanto do parcial. No primeiro caso, trata-se de um instrumento que bloqueia a mudança da legislação. No segundo, o presidente pode promulgar os artigos do projeto que sejam consensuais e remeter para reconsideração do Congresso somente as partes que foram vetadas. Embora sejam instrumentos cuja iniciativa está nas mãos do Executivo, a última palavra, de qualquer forma, é do Congresso. Tanto o veto total quanto o parcial podem ser derrubados pelo Legislativo, desde que aprovado por maioria absoluta. A permanência 
do veto indicaria que prevaleceu a vontade do Executivo. A derrubada, por sua vez, expressaria sua derrota.

Não há dúvida de que vetos derrubados e projetos rejeitados são sinais de derrota do Executivo, mas rejeição explícita de projetos do Executivo e a derrubada de vetos são fenômenos bastante raros. Segundo dados de Ricci (2001) entre 1990 e 1998, o Executivo teve 1.400 leis sancionadas, quinze projetos com veto total e quinze rejeitados. Não há informação quanto ao resultado da votação dos vetos, se foram mantidos ou derrubados. "Rejeição" e derrubada de vetos não são as únicas formas de "não aprovação" das matérias do Executivo. Empiricamente, sabe-se que há inúmeras proposições do Executivo retiradas ou que permaneceram em tramitação durantes anos ${ }^{3}$. Esses resultados significam necessariamente derrota?

Projetos retirados pelo autor (RTPA) podem ser interpretados pelos adeptos da tese de paralisia decisória como exemplos das dificuldades enfrentadas pelo Executivo para aprovação de sua agenda. O presidente prevendo uma possível rejeição da matéria pelo Legislativo solicita sua retirada, evitando, assim, o seu arquivamento. Projetos que permanecem em tramitação indefinidamente exemplificariam também a fraqueza do Executivo em conseguir apoio aos seus interesses. "Engavetar" o projeto em uma das comissões temáticas seria um recurso estratégico do Legislativo, mais vantajoso que levar o projeto a voto e rejeitá-lo.

O fato de haver proposições não aprovadas, originárias do Poder Executivo, remete-nos a outras questões. O envio de uma proposição corresponde necessariamente à preferência sincera do autor, isto é, o Executivo quer realmente que o projeto seja aprovado? Ao submeter uma proposição à apreciação do Congresso, o Executivo espera aprová-la na íntegra, sem qualquer modificação?

Partindo-se do pressuposto de que, nos sistemas de separação de poderes, processos de negociação entre Executivo e Legislativo são o modus operandi do exercício de governar (Cameron, 2000), a possibilidade do uso de ações estratégicas e de determinados instrumentos para a formação da legislação não devem ser desconsiderados. Objetivos e estratégias conjugam-se. Se o Executivo deseja realmente aprovar uma determinada matéria, pode se valer das seguintes estratégias: 1) radicalizar no conteúdo da proposta para na negociação ceder em determi- 
nados aspectos; e 2) utilizar todos os meios institucionais para neutralizar possíveis instâncias de vetos.

O acompanhamento da tramitação das proposições apresentadas pelo Executivo e não aprovadas evidencia que a sua mera identificação não revela toda a trama nas relações entre Executivo e Legislativo. Para tanto, é necessário que se leve em consideração que, por vezes, a não aprovação de projetos não significa a existência de bloqueio institucional do Legislativo.

Neste artigo, apresento uma interpretação diversa da que até então tem prevalecido como explicação para a não aprovação de determinadas matérias apresentadas pelo Executivo. Utilizo, para tanto, as propostas de reforma da legislação do trabalho apresentadas pelo Poder Executivo, entre 1987 e 2001. A reforma trabalhista é um bom exemplo de reforma anunciada e não concretizada ou apenas parcialmente concretizada, uma vez que projetos importantes nessa área só vieram a ser aprovados na gestão do presidente Fernando Henrique Cardoso.

Do governo do presidente Sarney até o final do segundo mandato de Fernando Henrique, dezenove propostas de "reforma trabalhista" foram apresentadas e apenas oito delas foram aprovadas, sendo cinco originárias de medidas provisórias. Esse resultado poderia ser utilizado como comprovação da tese de que os presidentes no Brasil estão condenados à paralisia de decisões, com o Executivo encontrando sérias dificuldades em implementar sua agenda, porque: a) o Legislativo mostra-se pouco disposto a cooperar; e b) o sucesso do Executivo depende do recurso à edição de Medidas Provisórias - MPs, isto é, a Presidência só legisla quando exclui o Legislativo do processo de definição de políticas (Rodrigues e Zauli, 2002; Pessanha, 2001; Couto, 2001).

As proposições apresentadas pelo Executivo e não aprovadas tiveram os seguintes resultados: 1) foram retiradas pelo próprio proponente - $\mathrm{o}$ Projeto de Lei - PL 164/87 apresentado por Sarney e o PL 4.893/95 apresentado por Fernando Henrique em seu primeiro mandato; 2) retiradas pelo sucessor do proponente - o presidente Lula retirou um apresentado por Fernando Henrique, que, por sua vez, retirou dois de Collor e um de Itamar. Esses projetos são casos que exemplificam a mudança de agenda, em decorrência da troca do chefe do Executivo e não podem ser interpretados como sinal de fracasso; 3) permanecem em tramitação, por tempo indeterminado, quatro projetos apresentados por Fernando Henrique; 4) e uma proposição teve veto total. 
O Anexo 1 apresenta um resumo das proposições apresentadas e o resultado da tramitação.

É consensual na literatura que o Executivo detém poderes legislativos significativos, o que lhe permite controlar a agenda legislativa e agilizam a tramitação de suas proposições (uso de medida provisória, pedidos de urgência - seja a urgência constitucional que determina a apreciação da matéria em cada Casa legislativa em um prazo de 45 dias, ou a urgência solicitada pelo Legislativo). Sendo assim, o fato de uma proposição apresentada pelo Executivo ter ficado em tramitação indefinidamente significa que tais poderes de agenda não foram utilizados. A questão é saber por que tais poderes não foram utilizados. Há duas possibilidades: 1) recusa do Legislativo em apoiar a utilização desses recursos; 2) desinteresse do Executivo em utilizar recursos institucionais importantes, para matérias de pouco interesse.

A primeira possibilidade pode ser descartada, pois o Executivo não necessita do Congresso para apresentar uma medida provisória, embora precise do seu apoio para aprová-la. Quanto à urgência, o Legislativo poderia vir a se recusar a solicitá-la, mas ainda assim restaria ao Executivo a urgência constitucional, que depende, única e exclusivamente, de sua vontade. Dessa forma, a segunda possibilidade torna-se mais plausível, mas ainda assim é necessário esclarecer por que o Executivo apresentaria uma proposição, e não mobilizaria todos os seus recursos institucionais para aprová-la.

Pode ocorrer que, embora o Executivo apresente formalmente uma proposição, e até tenha interesse em vê-la a provada, não se trata de matéria prioritária. São matérias que podem tramitar no "tempo" estabelecido pelo Congresso. Por esta razão, o Executivo não recorre à utilização dos recursos que agilizam a tramitação do projeto. Por não ser prioritária, pode também vir a ser utilizada como instrumento de negociação com o Legislativo para a aprovação de proposições verdadeiramente prioritárias.

Deve-se ter em mente também que a agenda governamental não é algo fixo e pré-determinado. Ela vai se formando ao longo do processo. Questões conjunturais, muitas vezes, forçam o Executivo a tomar iniciativas não previstas em sua agenda. Uma matéria considerada prioritária, em um determinado momento, poderá deixar de sê-la, em face de outras questões que possam ter surgido no decorrer do processo. 
Neste artigo, mostrarei que a apresentação de proposições também pode vir a se tornar instrumento de negociação para a definição de uma determinada política. A diferença entre o caso norte-americano estudado por Cameron (2000) é que no Brasil os presidentes não estão limitados a apenas vetar projetos. Podem propor e têm prerrogativa exclusiva para tanto em certas áreas de legislação. Seus campos de ações estratégicos com vistas a obter resultados políticos, obviamente, são bem maiores. Assim, sucesso e fracasso poderiam ser indicados não mais pelo cômputo puro e simples das proposições do Executivo que foram apresentadas e aprovadas, mas pela verificação se a estratégia utilizada surtiu ou não o efeito desejado.

A análise procura demonstrar que:

1) O anúncio ou o encaminhamento de uma proposta ao Congresso não deve ser interpretado como sendo, necessariamente, a preferência sincera do seu proponente. A iniciativa pode ter sido tomada para passar uma determinada imagem à opinião pública ou em resposta a grupos de pressão. Assim, não aprovação - que não seja rejeição - não deve ser tomada de antemão como indicador de fracasso do Executivo;

2) Há projetos apresentados pelo Executivo que não são prioritários ou que, em um determinado momento, deixaram de sê-lo. São matérias que foram utilizadas como "instrumentos de negociação". Questões conjunturais podem influenciar significativamente a tramitação de um determinado projeto;

3) Podem ocorrer também erros na estratégia adotada pelo governo ou no acompanhamento dos procedimentos legislativos que acabam por inviabilizar a tramitação do projeto;

4) O Executivo age estrategicamente e, para isso, lança mão de recursos institucionais para neutralizar instâncias de veto, acelerar a apreciação de suas propostas, e/ou conter a ação de grupos de pressão.

A análise toma como objeto empírico as proposições apresentadas pelo Poder Executivo que derrogariam ou modificariam a legislação trabalhista e sindical, especialmente as que: alteram o contrato e as condições de trabalho, no tocante às formas de contratação (flexíveis ou com determinados prazos, redução de encargos sociais, flexibilização dos mecanismos existentes de indenização nos casos de rescisão contratual etc.); e as que tratam do direito coletivo de trabalho (negociação coletiva, direito de greve e organização sindical) e do direito processual. 
Escolhi as propostas de mudança na legislação trabalhista e sindical porque essa área temática atende a dois critérios fundamentais para os objetivos aqui propostos. Em primeiro lugar, a "política pública" escolhida deveria estar na agenda governamental durante um período de tempo não muito restrito, pois de outra maneira seria impossível avaliar quais aspectos da interação Executivo-Legislativo permaneceram as mesmas e quais mudaram no decorrer do tempo. Em segundo, tendo a intenção de obter uma real perspectiva institucional, a política escolhida não poderia ser "área de domínio" preponderante seja do Congresso ou do presidente.

As propostas de reforma da legislação trabalhista e sindical atendem a esses requisitos. A permanência de tal tema na agenda governamental ajuda na avaliação do papel desempenhado tanto pelo Poder Executivo quanto pelo Legislativo como "produtores de políticas", na capacidade do Legislativo de impor controles à ação do Executivo e de assegurar espaço para a sua participação no processo decisório. A análise é feita a partir dos tipos de resultados, caracterizando, ao analisar projetos específicos, as estratégias empregadas pelo Executivo. Ao mesmo tempo, a caracterização de cada termo presidencial vai sendo construída.

Inicio a análise com o projeto apresentado por Sarney, sobre reforma sindical, mostrando que o governo não tinha interesse em aprová-lo. Tratava-se de tema polêmico, em uma agenda já bastante tumultuada em face do processo de transição política e da elaboração de uma nova Constituição. Mostrarei que o Executivo agiu estrategicamente, jogando para o Congresso a pecha de inativo, para posteriormente solicitar a retirada da matéria. Sigo com a análise dos demais projetos retirados, para em seguida tratar daqueles que permanecem em tramitação. A segunda seção concentra-se nos projetos que de fato sofreram bloqueio por parte do Legislativo. Trata-se das proposições enviadas por Collor. Na última seção, analiso os projetos aprovados e o relativo sucesso de Fernando Henrique.

\section{OS PROJETOS RETIRADOS PELOS PRÓPRIOS PROPONENTES}

A apresentação da proposta de reforma no governo Sarney foi motivada, em grande medida, pelas ações do movimento sindical com o chamado novo sindicalismo, que clamava por reforma na estrutura sindical corporativa e pela aprovação, na Câmara de Deputados no final do 
governo Figueiredo, da Convenção 87 da Organização Internacional do Trabalho - OIT assinada pelo governo brasileiro em $1949^{4}$.

Face ao debate gerado em torno da questão da Convenção 87, bem como à intensa movimentação grevista do período ${ }^{5}$, dois temas estavam postos no âmbito das relações de trabalho: o direito de greve e a mudança da estrutura sindical corporativa. No final de maio de 1985, o Ministro do Trabalho tornou público um anteprojeto de lei regulamentando a negociação coletiva e o direito de greve. Em entrevista ao jornal Folha de S. Paulo de 7/7/1985, o ministro Pazzianotto ressaltou que o anteprojeto não tinha caráter definitivo. Tratava-se de uma proposta "apresentada para ser debatida e reformulada através de sugestões as mais urgentes - dos vários setores" (Sallum Jr., Martins e Graeff apud Almeida, 1988:357).

O anteprojeto desagradou tanto aos empresários quanto às entidades sindicais de trabalhadores. As entidades empresariais (Confederação Nacional da Indústria - CNI, Federação das Indústrias do Estado de São Paulo - FIESP, Associação Nacional dos Fabricantes de Veículos Automotores - Anfavea e Associação Comercial de São Paulo) não concordavam com a "qualificação da greve" como procedente ou improcedente. As entidades sindicais de trabalhadores (representadas pela Central Única dos Trabalhadores - CUT e pela Confederação Geral dos Trabalhadores-CGT), por sua vez, criticavam o fato de o projeto ter como ponto de partida a Lei 4.330 que proibia a realização de greves, nos serviços considerados essenciais e no setor público. Solicitavam que, primeiramente, fosse revogada a legislação que limitava o "direito irrestrito de greve", para então se discutir uma nova legislação. Diante das críticas, o anteprojeto foi retirado para reformulações.

Em 1987, o governo apresentou o PL 164/87, dispondo sobre organização sindical ${ }^{6}$, direito de greve e negociação coletiva. Seus principais pontos eram: liberdade de organização dos sindicatos de acordo com a opção de empregados e empregadores, garantida a escolha do sistema a adotar, de unidade voluntária ou não; abolição do reconhecimento dos sindicatos por parte do Ministério do Trabalho; extinção gradual da contribuição sindical, dentro de um período de cinco anos; exigência de um número mínimo de associados, no caso de fundação de um segundo sindicato na mesma base; possibilidade de criação de sindicatos por categoria, por profissão, empresa ou por estabelecimento; permissão para organização das centrais sindicais; proibição de interven- 
ção ministerial nos sindicatos e de cassação de dirigentes eleitos, dentre outras medidas (Oliveira, 2002; Almeida, 1988; Keller, 1995).

O PL 164/87 apresentado por Sarney não chegou a ser apreciado pela Câmara. O projeto foi apresentado, exatamente, no mesmo dia em que a Mesa da Câmara dos Deputados, por unanimidade, aprovou uma resolução, determinando que as tramitações de todas as proposições legislativas ficariam suspensas até a promulgação da Constituição (Ato da Mesa $\mathrm{n}^{\mathrm{o}}$ 1, de 1987). Com a apresentação desse projeto, o Executivo sinalizou à sociedade que estava atendendo às pressões por reforma na legislação sindical, mas não houve um verdadeiro comprometimento para a sua aprovação. Não deve ser coincidência a apresentação da proposição exatamente no mesmo dia em que o Congresso aprovou resolução, suspendendo a tramitação das matérias nas Casas Legislativas. Nesse caso, os dois poderes favoreceram-se. O Executivo passou a informação à opinião pública que havia tomado a iniciativa de apresentar a proposição. A pecha de inativo ficaria com o Legislativo. Este, por sua vez, poderia justificar a não aprovação, em decorrência da suspensão dos trabalhos legislativos.

Em 1988, Sarney solicitou a retirada do projeto, apresentando como justificativa a necessidade de ajustá-lo às novas disposições constitucionais. Isso porque, com a promulgação da Constituição, em que uma série de garantias à atuação sindical adquiriu status constitucional, não havia mais interesse nem condições políticas de se manter em pauta uma proposta que, em muitos aspectos, se encaminhava contrariamente à nova Carta.

O outro caso de projeto retirado pelo próprio proponente é bem mais simples. Trata-se do PL 4.893/95 instituindo a lei de processo de trabalho, apresentado e retirado por Fernando Henrique. O projeto legislava sobre temas incorporados a dois outros projetos que foram aprovados: o PL 4.693/98, que instituía o "rito sumário"; e o PL 4.694/98, que dispunha sobre a criação das comissões de conciliação. A retirada do PL 4.893/95 não está relacionada ao bloqueio do Legislativo. Foi retirado porque, segundo "exposição de motivos" do ministro do Trabalho Paulo Paiva (ver Mensagem 241/1998, do Poder Executivo), o Ministério tinha interesse em reexaminar a matéria, o que ocorreu com a apresentação de novos projetos. 


\section{OS PROJETOS RETIRADOS POR SUCESSORES DO PROPONENTE}

Dentre os treze projetos de leis apresentados, quatro deles foram retirados pelos sucessores do proponente. Dois projetos de Collor e um de Itamar Franco foram retirados por Fernando Henrique, que, por sua vez, teve um projeto retirado por Lula. Projetos que deixaram de ser apreciados em razão de solicitação feita pelo sucessor podem indicar dificuldades na tramitação. Pode-se argumentar que o governo perdeu a oportunidade de provar o projeto dentro do mandato presidencial, por causa dos obstáculos criados pelo Legislativo. Como mostrarei, não é este o caso em nenhuma das matérias com esse destino.

A história dos PLs 1.231/91 e 1.232/91 oriundos do desmembramento do PL 821/91 apresentado por Collor, retirados por solicitação de Fernando Henrique, é complexa e será esclarecida adiante, quando tratarei dos projetos que de fato sofreram bloqueio por parte do Legislativo. No momento, basta dizer que essas propostas foram enviadas por Collor, após o veto presidencial ao Projeto de Lei de Conversão - PLV 58, que alterava uma medida provisória que ele mesmo enviara, extinguindo o imposto sindical dentre outras medidas. Os PLs 1.231/91 e 1.232/91 tramitaram em rito ordinário, em uma instância institucional, a Comissão de Trabalho, de Administração e Serviço Público CTASP, da Câmara formada por parlamentares pouco favoráveis à aprovação dos projetos.

A tramitação desses projetos estendeu-se até o segundo mandato de Fernando Henrique, que, por sua vez, solicitou a retirada. Tratava-se de matéria que não mais interessava ao presidente em exercício manter em tramitação, especialmente porque, durante a apreciação desses projetos, os partidos de oposição haviam conseguido alterar por completo a proposta original. Tais propostas foram os únicos casos de veto explícito por parte do Legislativo, dos quais tratarei adiante.

A justificativa do governo para a retirada dos projetos era de que o Ministério do Trabalho tinha interesse em reexaminar a matéria. A retirada é endossada também pelo ministro da Justiça, que, ao ser consultado pela Secretaria Geral da Presidência da República sobre a validade jurídica do pedido de retirada, esclarece que além de ser matéria de competência do Ministério do Trabalho - caberia, portanto, àquele Ministério decidir pela retirada ou não do projeto - soma-se o "fato de que a propositura em questão sofreu várias alterações no decorrer desses nove anos de tramitação na Câmara de Deputados" , alterações que não 
interessavam ao governo manter (ver Mensagem 240/1998 e 1720/2000, Poder Executivo).

O PL 4.768/94, apresentado por Itamar Franco, dispondo sobre a criação das comissões paritárias de conciliação, tratava do mesmo tema proposto pelo PL 4.694/98, apresentado posteriormente por Fernando Henrique. Quando este obteve a provação ao seu projeto, solicitou que o de seu antecessor fosse retirado da pauta. A justificativa do ministro do Trabalho Francisco Dornelles é bastante eloqüente nesse sentido: o PL 4.694/98 teria sido "fruto da atuação harmônica dos Poderes Executivo, Legislativo e Judiciário, que conjugaram esforços e célere aprovação da referida lei, que constitui avanço significativo no processo de modernização das relações de trabalho. [Estando em tramitação] matéria análoga com menor propriedade, permito-me sugerir sua retirada" (Mensagem 553/2000, Poder Executivo). O reconhecimento do ministro vale ser ressaltado: havia duas propostas análogas tramitando. Isto nos diz da estratégia do Executivo, qual seja: apresentar uma nova proposição ao invés de se valer de matéria similar já em tramitação.

O PL 5.483/01 apresentado por Fernando Henrique, no seu segundo mandato, além de ser um dos casos de projeto apresentado por um presidente e retirado por solicitação de outro, também exemplifica como a "agenda" do Executivo passa por momentos de reconstituição, a depender muitas vezes, de questões conjunturais, e como uma proposição pode ser utilizada como "moeda de negociação", na medida em que outras propostas passam a ser consideradas prioritárias pelo governo.

O segundo mandato de Fernando Henrique foi marcado por tentativas de retomar a agenda de reformas estruturais. A reforma trabalhista foi uma dessas tentativas e, como as demais, não vingou, quer por força das questões conjunturais ditadas pelas sucessivas crises econômicas, quer pela falta de compromisso do governo com as reformas que iniciara.

Antes que o projeto de reforma trabalhista - PL 5.483/01 - fosse apresentado formalmente, o Executivo adotou a estratégia de, primeiramente, divulgá-lo na imprensa, para avaliar a reação da sociedade ("Ministro prepara ofensiva contra lei trabalhista", O Estado de S. Paulo, 27 /2 /2000). Em matéria publicada na Folha de S. Paulo (Caderno de Economia, 27/2/2000), o prof. José Pastore, em uma postura crítica a esta estratégia, assim se manifesta: "o papel do governo é explicar mui- 
to bem o que pretende fazer e por que - não pode haver uma política de balão de ensaio sobre as mudanças e depois ficar esperando a reação da sociedade. O desafio é justamente o oposto: explicar o que se quer, com paciência e completa clareza, de modo a não deixar uma só dúvida no $a^{\prime \prime}$.

A anunciada reforma tomou forma legislativa em 2001 através do PL 5.483 estabelecendo que prevalecesse o negociado sobre o legislado. $\mathrm{O}$ projeto contou com o apoio de algumas entidades patronais e da Força Sindical. Sete sindicatos dos metalúrgicos ligados a essa Central chegaram a aprovar, em assembléia, um acordo propondo a flexibilização de alguns direitos. No entanto, liminar concedida pela Justiça a pedido do Ministério Público do Trabalho suspendeu o acordo ${ }^{7}$. A CUT, por sua vez, posicionou-se contra, promovendo manifestações públicas em várias capitais do país.

O processo de votação do projeto na Câmara foi bastante tumultuado, e, à medida que o tempo passava, a não deliberação desse projeto começou a atrapalhar o próprio governo. Dois outros projetos importantes aguardavam inclusão na pauta e não podiam ser apreciados em razão da urgência do PL 5.483/01: o que regulamentaria o lobby; e o que permitiria a entrada de capital estrangeiro nas empresas de comunicação ${ }^{8}$. Quando o projeto finalmente chegou ao Senado, estava em discussão no Congresso a "renovação" da Contribuição Provisória sobre Movimentação Financeira - CPMF, cujo prazo havia expirado, comprometendo seriamente a continuidade de uma série de programas do governo ${ }^{9}$.

Aproveitando-se da crise na aliança PSDB-PFL ${ }^{*}{ }^{10}$ a oposição condicionou seu apoio à CPMF à retirada da urgência do PL 5.483/01. O governo assim o fez. A urgência foi retirada, e o projeto permaneceu em tramitação no Senado até que, em 30/4/2003, o presidente Lula solicitou sua retirada da pauta.

Este é o único caso de tramitação longa em que a extensão, em um primeiro momento, se deveu a alguma dificuldade de aprovação. Porém, não se deve esquecer que houve uma certa demora do Executivo em apresentar a proposição. Isso porque, como se sabe, o segundo mandato de Fernando Henrique foi marcado pela precipitação da crise cam-

\footnotetext{
* Ver lista de siglas de partidos políticos com os respectivos significados ao final do artigo.
} 
bial, obrigando o Executivo a concentrar-se na gestão de curto prazo da política econômica (Oliveira, 2002). Quando finalmente o texto tomou forma de proposição legislativa, ao tempo que o projeto era debatido e analisado nas Casas Legislativas, outras questões prioritárias para o governo estavam em pauta, inclusive a administração da crise política com o PFL quanto à sucessão presidencial. Não fossem esses aspectos, muito provavelmente o projeto teria sido aprovado pelo Senado e sancionado pelo presidente.

O argumento até aqui apresentado é que projetos retirados não devem ser interpretados como exemplos das dificuldades enfrentadas pelo Executivo para aprovação de sua agenda. Os casos relatados revelam que a retirada de projetos está mais relacionada à mudança da agenda política do que a uma eventual resistência do Legislativo à aprovação das matérias.

\section{PROJETOS EM TRAMITAÇÃO}

Projetos que permanecem por um longo período em tramitação também costumam ser interpretados como evidência de derrota ou pelo menos como sinal de dificuldades enfrentadas pelo Executivo. Para o Legislativo, deixar um projeto tramitando indefinidamente pode ser um recurso estratégico mais eficiente que o rejeitar. Ocorre que o Executivo dispõe de mecanismos institucionais que podem agilizar a tramitação do projeto, evitando possíveis instâncias de veto. Há, portanto, dois aspectos a serem verificados: a) se o Executivo se valeu desses recursos, e, sendo afirmativa a resposta, se o Legislativo se negou a apoiar sua utilização; b) se o Executivo não lançou mão desses mecanismos, a questão é entender por que não o fez. Há duas possibilidades: trata-se de matéria não prioritária e, portanto, pode tramitar "ao tempo" do congresso, ou; trata-se de matéria cujo principal objetivo do governo não é aprová-la, mas sim utilizá-la como instrumento de negociação ou mesmo de pressão.

Os projetos apresentados por Fernando Henrique e que permanecem em tramitação até hoje ilustram essas questões. São eles: o PL 3.003/97, dispondo sobre contribuição negocial do sistema confederativo, o PL 3.748/97 sobre validação da rescisão contratual feita pelos sindicatos, o PL 4.302/98 sobre trabalho temporário e o PL 1.802/96 sobre direito de greve. $\mathrm{O}$ único que avançou em termos de deliberação foi o PL 4.302/98, que atualmente está em tramitação na Câmara para aprecia- 
ção do substitutivo apresentado pelo Senado. O PL 3.003/97 foi anexado ao PL 5.169/90 e está em tramitação na Comissão de Trabalho, o PL 3.748/97 está em poder da Mesa em razão da apresentação de um requerimento solicitando que o Plenário se manifestasse sobre o projeto, e o PL 1.802/96 foi anexado ao PL 401/91 de autoria do deputado Paulo Paim, que se encontra em tramitação na CTASP.

A interpretação de que a tramitação dos projetos não avançou porque o Legislativo bloqueou sua apreciação, em um certo sentido, não está errada, mas deve-se levar em conta o desinteresse do Executivo em agilizar a tramitação dessas matérias. Nesses projetos, à exceção do PL 4.302/98, o Executivo permitiu que os projetos tramitassem em regime ordinário, e, ao não solicitar urgência a esses projetos, governo e base governista não tentaram evitar que os membros da CTASP atuassem como atores com poder de veto, o que demonstra um certo desinteresse do governo em agilizar a apreciação desses projetos.

No caso do PL 1.802/96 deve-se agregar mais um aspecto - o fato de a apresentação de uma proposição ser utilizada como instrumento de pressão para conter eventuais opositores à agenda prioritária do governo. A apresentação desse projeto estava relacionada a uma questão maior - garantir a estabilidade do Plano Real; para isso, seria necessário colocar um freio à ação sindical. A compreensão desse processo exige comentários mais extensos e esclarecimentos quanto ao contexto político no qual ele se insere.

Logo no início do primeiro mandato de Fernando Henrique, mais especificamente, em maio de 1995, os petroleiros deflagraram uma greve que culminou com a ocupação das refinarias pelo exército ${ }^{11}$. Agreve foi considerada abusiva pelo Tribunal Superior do Trabalho - TST, que determinou a aplicação de uma multa no valor de $\mathrm{R} \$ 100$ mil diários para os sindicatos, caso os trabalhadores não voltassem imediatamente ao trabalho. A partir de então, iniciou-se o bloqueio das contas das entidades, retenção das receitas e penhoras de bens. O valor da multa decretada pelo TST acumulou-se, gerando uma dívida incompatível com o patrimônio dos sindicatos penalizados (Martins e Rodrigues, 2000:158).

Em face às dificuldades enfrentadas pelas entidades sindicais, o Legislativo aprovou um projeto de lei que as anistiava do pagamento das multas, assim como os sindicalistas demitidos. O projeto foi totalmente vetado pelo presidente, que enviou um novo projeto - o PL 1.802/96 
-, permitindo aos Tribunais do Trabalho, ao julgarem a ilegalidade de uma greve, fixarem multas diárias contra os sindicatos no valor de até 500 salários mínimos. A proposta também previa a possibilidade de suspensão do pagamento da multa, no todo ou em parte, desde que, decorridos cinco anos, o sindicato não tivesse promovido greves abusivas (ver Diário da Câmara dos Deputados, 1/5/1996, p. 12.084).

Ogoverno queria, acima de tudo, dar sinais claros que não toleraria ser desafiado pelo movimento sindical, como havia acontecido com seus antecessores, e que não permitiria que se abrisse qualquer precedente que pudesse incentivar a deflagração de paralisações em outras categorias dos servidores públicos.

Mais tarde, já no final do primeiro mandato, com o movimento sindical mais contido face aos índices crescentes de desemprego e à perda de seu poder sindical, o Executivo sancionou o PL 4.573/98 de autoria do deputado José Eduardo Dutra (PT), concedendo anistia das multas aplicadas pelo TST às entidades sindicais dos petroleiros. A versão original do projeto previa restituição de importâncias eventualmente retidas, em decorrência de sentença normativa ou acordo coletivo de trabalho, às instituições sindicais. Esse artigo foi vetado pelo presidente, que, na mensagem enviada ao Congresso justificando porque vetou o artigo, deixa claro qual o propósito da apresentação do PL 1.802/96:

\begin{abstract}
“[...] considerando-se que o elevado montante de multas continua efetivamente a inviabilizar o funcionamento dos sindicatos petroleiros, $j a ́$ tendo efeito pedagógico a postura adotada pela Justiça do Trabalho, Ministério Público e Governo na responsabilização dos sindicatos que agiram com flagrante atentado à ordem institucional da sociedade, pode-se sancionar o projeto, desde que vetado o parágrafo único do artigo 1음 (Mensagem 761, Diário do Congresso Nacional, 11/11/1998, p. 12.814, ênfases minhas).
\end{abstract}

Ao Executivo, pouco importava que o PL 1.802/96 permanecesse em tramitação. Seu "efeito pedagógico" já havia sido alcançado.

Tratei até aqui dos projetos retirados e dos que permanecem em tramitação. As evidências reunidas demonstram quanto podem ser equivocadas conclusões tiradas a partir do simples resultado da tramitação de uma proposição. Nem sempre projetos retirados e que permanecem indefinidamente em tramitação são sinais de derrota do Executivo. 


\section{OS VETOS DO LEGISLATIVO}

A afirmação de que os projetos não aprovados não devem ser tomados, de antemão, como exemplos das dificuldades encontradas pelo Executivo na implementação de sua agenda, não significa total inexistência de conflito entre Executivo e Legislativo. Divergências existiram, mas ao menos no campo da legislação social do trabalho, de forma muito mais localizada do que supõe parte da literatura que analisa as relações entre os Poderes no Brasil. Os projetos que sofreram bloqueio pelo Legislativo foram os apresentados por Collor. $\mathrm{O}$ insucesso deste presidente costuma ser usado como exemplo do destino de presidentes minoritários em regimes de separação de poderes.

A agenda de reformas na área trabalhista proposta por Collor representou, em grande medida, uma tentativa de reverter alguns aspectos da legislação social do trabalho estabelecidos pela Constituição de 1988. No que diz respeito a essa legislação, a pretendida reforma do Estado $^{12}$, anunciada por Collor, iniciou-se através da apresentação da MP 215/90, extinguindo a contribuição sindical de forma imediata ${ }^{13}$.

AMP não foi apreciada dentro do prazo de trinta dias, sendo reeditada por mais três vezes até que na última reedição, MP 275, o Congresso apresentou o PLV 58, extinguindo gradualmente o imposto, em um prazo de cinco anos, com redução do seu valor em $20 \%$ a cada ano. $\mathrm{O}$ projeto foi inteiramente vetado pelo presidente, que não abria mão da extinção imediata da contribuição (Gomes e D'Araújo, 1993:345). Vetando o PLV aprovado, Collor acabou por manter o status quo original.

O veto presidencial em torno dessa medida provisória deve ser visto em um contexto maior. Tratava-se por um lado do "envio" de uma mensagem ao Congresso: o presidente não aceitava negociar esse ponto da sua agenda. Por outro, expressava um conflito entre o presidente Collor e o PMDB que vinha se materializando desde a apreciação das medidas provisórias do plano econômico.

De acordo com Figueiredo e Limongi (1999:141), com o lançamento do pacote econômico, a intenção do governo era aprovar as medidas provisórias sem qualquer alteração. O PMDB, por sua vez, buscava forçar o governo a fazer concessões, uma vez que era a maior bancada partidária do Congresso e detinha os votos necessários para aprovação do plano. Em resposta às modificações propostas pelos relatores das medidas provisórias (a maioria deles do $\mathrm{PMDB}$ ), o presidente recorria ao 
veto para anular essas modificações. Assim, o veto à MP do imposto sindical não foi um caso isolado. A comissão mista encarregada de apreciar a medida que deu origem ao PLV 58 era majoritariamente peemedebista e teve como relator o deputado Mário Lima também do PMDB.

A partir de 1991, o governo buscou redefinir suas relações com os partidos políticos e com o próprio Congresso. Uma reforma ministerial ampliou a base de apoio do governo. Reduziu-se a emissão de medidas provisórias, e, em seu lugar, propostas começaram a ser encaminhadas via projetos de lei (idem:142).

É nesse contexto que o governo encaminha o projeto 821/91 sobre organização sindical e negociações coletivas de trabalho. O projeto capacitava o Ministério do Trabalho para reconhecimento legal dos sindicatos enquanto representantes dos trabalhadores, para resolver divergência de enquadramento sindical e para baixar instruções sobre representatividade sindical. Previa, ainda, interferência das empresas nos recolhimentos de contribuições sindicais; admitia a flexibilização de direitos através da negociação coletiva; limitava a até seis meses, após o vencimento, a vigência dos acordos normativos; permitia a substituição do contrato individual de trabalho pelo contrato coletivo flexibilizado, dentre outros aspectos. Quanto ao imposto, sugeria que fosse extinto entre os anos de 1992 e 1993 na base de 50\% ao ano, rendendo-se, assim, à sua extinção gradual, ainda que em prazo bem menor ao proposto pelo Congresso.

A reação do Congresso foi imediata. Na Câmara de Deputados, o projeto foi encaminhado para apreciação da CTASP. Uma instância institucional que à época, além de ser presidida pelo PT, contava ainda com número significativo de parlamentares (cerca de $30 \%$ dos seus membros) vinculados aos partidos de esquerda; e com $22 \%$ vinculados ao PSDB e PMDB; uma bancada sindicalista que correspondia a $27 \%$ do total de membros; $\mathrm{e}$, ainda, dentre os que não pertenciam nem ao bloco de partidos de esquerda, nem tampouco à "bancada sindical", haviam deputados bastante afinados com as questões trabalhistas e sindicais ${ }^{14}$.

Nessa instância, a reação dos parlamentares não poderia ser outra, a não ser de oposição. O PL 821/91 foi desmembrado em dois novos projetos, através da mensagem 189/91: um dispondo sobre organização sindical (PL 1.231/91), outro sobre negociação coletiva (PL 1.232/91). Os pareceres do deputado Aldo Rebelo (PC do B) foram pela apresen- 
tação de substitutivos que descaracterizaram a proposta original. Os substitutivos foram aprovados de forma unânime pela CTASP em junho de 1991.

Ao PL 1.231/91, não foi sequer solicitada urgência. O PL 1.232/91 tramitou sob urgência constitucional (apreciação em 45 dias em cada Casa), mas em um certo momento de sua tramitação, atendendo a pedido de Collor, o líder do governo, deputado Ricardo Fiúza, solicita sua retirada, levando o projeto a tramitar em rito ordinário. Tais projetos permaneceram por quase dez anos em tramitação até serem retirados por solicitação de Fernando Henrique, e exemplificam os limites existentes aos poderes de agenda do Executivo.

Em junho de 1992, Collor criou a Comissão de Modernização da Legislação do Trabalho, com o propósito de restabelecer o sentido original de suas propostas. Contudo, essa comissão só concluiu seus trabalhos em novembro daquele ano, ou seja, depois do impeachment do presidente.

Não fosse o erro estratégico cometido pelo presidente ao vetar o PLV que propunha a extinção gradual do imposto sindical, teríamos aprovado há quatorze anos ao menos parte da tão propalada reforma sindical.

\section{PROPOSTAS APROVADAS}

Foi dito anteriormente que, se o Executivo deseja realmente aprovar uma determinada matéria, pode adotar as seguintes estratégias: radicalizar no conteúdo da proposta, para ceder na negociação e, paralelamente, recorrer a seus recursos institucionais para neutralizar instâncias de veto.

O uso das medidas provisórias, apresentadas e reeditadas durante o governo do presidente Fernando Henrique, e a solicitação de urgência aos projetos de leis são exemplos dos instrumentos utilizados pelo presidente para conseguir aprovação às matérias que eram de seu interesse. As medidas provisórias podem ser vistas como: 1) afirmação da agenda, pois entram em vigor imediatamente; 2 ) formas de contornar resistência do Congresso.

O fato de entrarem em vigor imediatamente não as exime de serem objeto de negociação. Modificações substantivas no texto na passagem de uma reedição a outra são sinais claros de negociação entre Executivo e 
Legislativo. Por outro lado, o uso de MP como forma de contornar resistências é bem limitado. Inúmeros casos retratados durante o governo de Collor mostraram que o recurso de emitir MP não é eficaz, se a matéria proposta não tem apoio da maioria.

A vantagem em emitir MPs já foi explicitada pelos estudos que tratam do tema: entrada em vigor a partir da emissão, evitar que o parlamentar se exponha sobre temas conflitantes etc. Há, no entanto, outro aspecto bastante vantajoso para o governo na emissão de uma MP - o fato de sua base de sustentação ter maior controle sobre o processo decisório.

Como se sabe, medidas provisórias devem ser apreciadas por comissões parlamentares especiais, formadas segundo critérios de proporcionalidade partidária, o que garante ao governo ter maioria nessas instâncias deliberativas e controle dos cargos de presidente e relator.

A emissão de medidas provisórias no governo Fernando Henrique, para além de ser uma ferramenta de afirmação da agenda, foi também um instrumento de persuasão para que o Executivo mantivesse sob controle a principal meta de seu governo - preservar a estabilidade econômica alcançada com o Plano Real. Para tanto era necessário evitar: 1) contestações advindas do movimento sindical; e 2) que reajustes salariais fossem repassados aos preços.

O argumento do governo era que a indexação da economia através de algum acordo que vinculasse salários e os preservasse da desvalorização financeira seria um ataque ao Plano Real. Aumentos salariais, sobretudo no funcionalismo público, causariam o retorno da inflação e a penalização das camadas mais pobres que não poderiam recorrer à indexação como forma de preservação do seu poder de compra (Miagusko, 2001:71).

A greve dos petroleiros foi o primeiro grande embate entre o movimento sindical e o governo recém-eleito de Fernando Henrique, e serviu como freio às ações reivindicatórias dos sindicatos. Os petroleiros reivindicavam principalmente o cumprimento de um acordo firmado com Itamar Franco no final de seu mandato. Por serem uma categoria altamente articulada e mobilizada, teriam um papel destacado de liderança diante das outras categorias.

Ao tempo em que petroleiros e governo não chegavam a um acordo, a CUT começou a organizar os chamados "dias nacionais de luta", um 
movimento mais amplo e que reunia diversas categorias do funcionalismo público - telefônicos, trabalhadores do Correio, professores e funcionários das universidades federais e eletricitários -, os quais reivindicavam o cumprimento dos acordos salariais. Os petroleiros assumiram o papel de liderança e, antecipando sua plenária, decidiram pela realização de uma greve unificada de todo o funcionalismo para o dia 11 de abril de 1995 (idem:78).

A deflagração do movimento grevista resultou em uma estrondosa derrota para o sindicalismo de uma forma geral ${ }^{15}$. Pesadas multas foram impostas, pontos foram cortados, trabalhadores foram demitidos e o que é pior, aos olhos da opinião pública, tratava-se de categorias privilegiadas que, com suas paralisações, apenas contribuíam para penalizar a população. Para o ministro do Trabalho, Paulo Paiva "a greve (era) política e extemporânea [...] coisa da CUT contra as reformas da Constituição" (Folha de S. Paulo, 4/5/1995).

Com o enfrentamento do movimento sindical e com a apresentação de uma série de proposições legislativas, o governo atingiu seus principais objetivos. Logo após o movimento dos petroleiros, a MP 1.053/95 estabeleceu a livre negociação coletiva na definição de salários ${ }^{16}$. A partir de então, através das medidas provisórias, em várias oportunidades, o Executivo passou a sinalizar aos sindicatos até onde o governo poderia chegar para manter sua agenda governamental. Algumas MPs, em determinados momentos, impunham perdas às entidades sindicais, às vezes suprimidas em reedições futuras ou mesmo quando da promulgação da MP. Há casos que evidenciam que a mudança do texto na passagem de uma reedição a outra significou uma reavaliação por parte do Executivo, "um voltar atrás", amenizando os limites impostos às entidades sindicais. As medidas provisórias abaixo descritas retratam esses aspectos.

A MP 1.053/95, além de estabelecer a livre negociação coletiva na definição dos salários, também previa que se fosse frustrada a negociação direta, as partes deveriam, obrigatoriamente, antes do ajuizamento do dissídio coletivo, solicitar ao Ministério do Trabalho - MTb a designação de um mediador, a quem caberia concluir a negociação dentro de trinta dias ou lavrar um laudo para instruir o dissídio coletivo. Estava excluída a adoção, por meio de negociação ou dissídio, cláusulas de reajuste ou correção salarial automática vinculada a índice de preços, ou a concessão a título de produtividade, de aumento que não fosse ampa- 
rado em indicadores objetivos aferidos por empresa. Além disso, deveriam ser deduzidos na data-base todos os aumentos e revisões concedidos no período anterior (Oliveira, 2002).

Essa MP passou por inúmeras reedições. Em algumas delas, o governo acrescentava dispositivos que atingiam a atividade sindical. Em outras, apresentava versões mais brandas, muitas vezes voltando atrás nas deliberações emitidas pelas medidas anteriores. Uma das reedições, por exemplo, revogou a chamada ultra-atividade dos acordos coletivos, a qual permitia que um acordo ou convenção coletiva continuaria em vigor até que fossem explicitamente alteradas ou suprimidas por negociação coletiva, segundo o princípio da anualidade da data-base.

Em outra reedição, foram abrandadas as cláusulas relativas à mediação e à produtividade. A mediação deixou de ser obrigatória antes do ajuizamento de dissídio coletivo e passou a ser possível, também, a designação do mediador diretamente pelas partes (ibidem).

O governo também se valeu da prática de reedição para acrescentar temas não abordados nos textos anteriores. Em um determinado momento, a MP previa a criação do chamado "banco de horas", estabelecia contrato de trabalho a tempo parcial, e a extensão (facultativa) do benefício do Programa de Alimentação do Trabalhador - PAT ao trabalhador dispensado. A MP permitia a realização de contratos com uma jornada de até 25 horas semanais, mediante opção dos atuais trabalhadores manifestada perante a empresa ou na contratação de novos empregados.

Em novembro de 1998, o governo apresentou a MP que passou a prever a possibilidade de suspensão do contrato de trabalho, um mecanismo para adiar uma situação de iminente dispensa. Uma vez suspenso, ao empregado seriam oferecidos cursos de qualificação e, durante essa suspensão, que seria de dois a cinco meses, o empregado não receberia salário da empresa, mas uma bolsa de qualificação custeada pelo Fundo de Amparo ao Trabalhador - FAT, de valor correspondente ao do seguro-desemprego (Freitas, 2000:109; Oliveira, 2002). Após as inúmeras reedições, essa MP foi aprovada transformando-se na Lei nº 10.192.

A MP 1.070/95, reedição da MP 327 / 93 que criou o programa nacional de desestatização, tornou possível a adoção imediata do efeito suspensivo nos dissídios coletivos ${ }^{17}$, permitindo a uma das partes recorrer da 
decisão de um tribunal de instância inferior. No mesmo texto, a MP previa a adoção de alguns procedimentos para a implantação da mediação, de forma direta ou via Ministério do Trabalho (Castro, 2001:80). A última edição dessa MP, transformada na Lei 9.491/97, limitou-se a alterar procedimentos relativos ao "programa de desestatização" e, no que se refere a temas trabalhistas, apenas previu a utilização dos recursos do Fundo de Garantia do Tempo de Serviço - FGTS para aquisição de ações de empresas privatizadas.

AMP 794/94 sobre participação dos trabalhadores nos lucros e resultados das empresas (PLR), apresentada por Itamar Franco, foi reiteradamente reeditada durante o governo de Fernando Henrique. A primeira versão previa a presença dos sindicatos no processo de negociação. A segunda edição, MP 860/95, os excluía. Caberia às empresas formar uma comissão de representantes dos trabalhadores, eleitos entre os próprios, e aos sindicatos caberia apenas a função de arquivar o instrumento do acordo coletivo. A não-participação das entidades sindicais suscitou uma ação de inconstitucionalidade por parte de um grupo de entidades sindicais filiadas à CUT, preservando-lhes o direito de participar da negociação. Essa decisão só foi acatada pelo governo em junho de 1997, através da edição de um novo texto prevendo a participação dos sindicatos (Castro, 2001; Oliveira, 2002; Krein e Oliveira, 1999).

Uma nova edição da MP, em junho de 1998, tornou possível a negociação da PLR por meio de convenção ou acordo coletivo ou por uma comissão escolhida pelas partes, integrada também por um representante indicado pelo sindicato da respectiva categoria profissional, escolhido dentre os empregados da empresa. Essa última exigência foi suprimida nas últimas reedições da medida provisória, pois conflitava com o princípio da organização sindical por categoria e base geográfica (Oliveira, 2002). Outra reedição previa a utilização do chamado "banco de horas" e autorizava o trabalho aos domingos no comércio varejista. Este último aspecto foi incorporado ao texto aprovado e a criação do banco de horas, passando a constar do PL 1.724/98 e da MP 1.709/98.

A última versão da MP, Lei 1.0101/00, estabelece que a PLR deve ser objeto de negociação entre a empresa e seus empregados, por meio de uma comissão escolhida pelas partes, integrada também por um representante indicado pelo sindicato da respectiva categoria profissional, ou por meio de convenção ou acordo coletivo. A negociação deve estabelecer os direitos de participação nos lucros ou resultados, as condi- 
ções de pagamento, os mecanismos de aferição e o período de vigência. Para que não fosse substituída completamente a remuneração fixa, adotou-se uma periodicidade mínima de seis meses para as cláusulas de PLR (idem). A lei também prevê que, se fracassar a negociação direta, as partes podem recorrer, de comum acordo, à mediação ou à arbitragem, com força normativa independentemente de homologação judicial (idem; Martins e Rodrigues, 2000) ${ }^{18}$.

Além dessas medidas, a MP 1.523/96, determinando a rescisão contratual face à aposentadoria, entrou na agenda da "reforma trabalhista", porque o governo não conseguiu aprovar tal dispositivo na proposta de emenda constitucional da previdência. A MP foi aprovada, transformando-se na Lei 9.528/97.

O sucesso alcançado nessas matérias se explica não pelo fato de o Executivo ter recorrido a um instrumento discricionário, como defende parte da literatura, mas por ser também a emissão de MPs um valioso instrumento estratégico, apoiado pela base de sustentação, para o governo implementar sua agenda.

O controle, pela base governista, das comissões especiais encarregadas de apreciarem as medidas provisórias exemplificam essa situação de apoio. A comissão especial encarregada de apreciar a MP 1.523/97, por exemplo, era formada por quatro parlamentares do PFL; dois do PMDB, dois deputados do bloco (PMDB/PSD/PSL/Prona); dois parlamentares do PSDB; um senador do PPB; e um deputado do PTB, totalizando doze parlamentares da base governista. O bloco da oposição formado pelo PT, PDT, PSD e PPS foi representado por dois parlamentares.

Para apreciação das demais medidas provisórias, as comissões especiais não chegaram a ser formadas. Segundo Figueiredo e Limongi (1999:155), isso ocorreu com a maioria das medidas provisórias. “Quase sempre as comissões (foram) instaladas para designar o relator, que (passou) a conduzir, com ampla autonomia, as negociações com o governo". Este foi o caso da MP 794/94 sobre participação nos lucros, que teve como relator o senador Ney Suassuna (PMDB), e a MP 1.053/95 sobre desindexação salarial, cujo relator foi o deputado Jorge Cury (PTB).

À medida que o governo seguia reeditando as medidas provisórias, encaminhou, paralelamente, algumas propostas via projetos de lei. Primeiramente apresentou o PL 1.724/96, estabelecendo o contrato de trabalho por tempo determinado. Em 1998, encaminhou os PLs 4.691, 
4.692, 4.693, 4.694, 4.695 e 4.696. À exceção do PL 4693 (Lei 9.957/00) que criou o rito sumaríssimo da justiça do trabalho para causas de valor inferior a 40 salários mínimos; e do PL 4.694 (Lei 9.958/00) que possibilitou a instituição de comissões paritárias, com representantes de empregados e de empregadores, para tentar conciliar os conflitos individuais do trabalho, os demais limitavam-se a pequenas alterações e atualizações da legislação.

Para aprovação dos projetos de lei, o Executivo valeu-se da estratégia de: 1) retirá-los do âmbito da CTASP e apreciá-los em Plenário, porque, embora se tratasse de uma comissão presidida por parlamentares da base governista, parte significativa dos seus membros pertencia aos partidos de oposição, que poderiam recorrer a diversos mecanismos de obstrução evitando a apreciação dos projetos, e 2) evitar que parlamentares da oposição os relatassem ou que tivessem suas emendas aprovadas.

Os três projetos aprovados tramitaram em regime de urgência, o que impossibilitou que os membros da CTASP atuassem como atores com poder de veto, tiveram relatores da base governista, que, por sua vez, não apresentaram substitutivos (um indicativo de que acataram o texto proposto pelo Executivo), praticamente não houve aceitação das emendas apresentadas pelos parlamentares dos partidos de oposição e apenas em um projeto houve solicitação de votação nominal. O Quadro 1 apresenta um resumo da tramitação desses projetos.

\section{Quadro 1}

Projetos de Lei Aprovados

\begin{tabular}{|l|c|c|c|}
\hline $\begin{array}{l}\text { Informação quanto à Trami- } \\
\text { tação }\end{array}$ & PL 1.724/96 & PL 4.693/98 & PL 4.694/98 \\
\hline Partido Relator na CTASP & PFL & PSDB & PFL \\
\hline Urgência & Sim & Sim & Sim \\
\hline Relator em Plenário & PFL & PSDB & PFL \\
\hline Substitutivo & Não & Não & Não \\
\hline Emendas apresentadas & $\begin{array}{c}\text { Governo }-25 \\
\text { oposição }-36\end{array}$ & Governo -4 & $\begin{array}{c}\text { Governo }-2 \\
\text { Oposição }-4\end{array}$ \\
\hline Emendas aprovadas & $\begin{array}{c}\text { Governo }-10 \\
\text { Oposição }-1\end{array}$ & Governo -3 & Governo -1 \\
\hline Votação nominal & Não & Sim & Não \\
\hline
\end{tabular}

Fonte: Base de Dados Prodasen. 
Em resumo, o governo de Fernando Henrique caracterizou-se, acima de tudo, pela tentativa de preservar a estabilidade econômica e, para isso, não poupou meios e recursos. Propostas de mudanças na legislação do trabalho só foram apresentadas na medida em que os índices de desemprego começavam a atingir patamares significativos. Nesse sentido, a "agenda trabalhista" foi pautada por temas conjunturais, sempre respaldando a "agenda econômica" do governo.

\section{COMENTÁRIOS FINAIS}

Este artigo revelou que sucesso e fracasso da agenda presidencial não podem ser medidos apenas pela indicação do trâmite final da proposição. Se assim o fosse, a conclusão seria que os quatro últimos presidentes não implementaram sua agenda em face de um Legislativo hostil e pouco disposto a cooperar. O esforço aqui foi o de demonstrar que enviar projetos é parte de uma estratégia e que - não necessariamente aprovar é o objetivo primordial. Assim, as aparentes derrotas dos presidentes devem ser vistas nesse contexto.

Sarney não apresentou sua proposta de reforma sindical com o objetivo de aprová-la. A intensa mobilização por redemocratização, inclusive no que dizia respeito às relações de trabalho, foi o que motivou a apresentação da proposta. Mas tanto o Executivo quanto o Legislativo sabiam da impossibilidade de apreciação daquela matérias, às vésperas de uma Assembléia Constituinte.

Collor, ao que tudo indica, estava disposto a promover mudanças na legislação sindical, mas adotou uma estratégia de tudo ou nada. Em um primeiro momento cometeu o erro de avaliação de que, através do uso de medidas provisórias, poderia driblar o Congresso. A resposta do Legislativo veio através do PLV, que moderava a proposta presidencial, mas mantinha seu cerne. $\mathrm{O}$ presidente não aceitou as mudanças apresentadas pelo Congresso, vetando o PLV, mantendo, assim, o status quo. Quando optou por apresentar a proposta de reforma sindical via projeto de lei, já era tarde demais. Seu governo começava a se desmantelar em face das acusações de corrupção.

O cenário de instabilidade econômica e o próprio caráter interino do governo do presidente Itamar Franco inviabilizaram qualquer tentativa de reforma mais ampla. As iniciativas presidenciais restringiram-se à apresentação de uma medida provisória (sobre participação nos lucros) e um projeto sobre criação de comissões paritárias. A MP passou 
por uma série de mudanças já no governo de Fernando Henrique, enquanto o projeto acabou sendo retirado e arquivado.

A gestão de Fernando Henrique foi a mais bem-sucedida. Embora a "agenda trabalhista" estivesse subordinada à "agenda econômica", os projetos que interessavam ao governo foram aprovados. Os que não o foram, como já mencionado anteriormente, não devem ser interpretados como prova cabal de uma relação de conflito entre os Poderes. Muitos projetos foram utilizados como "instrumento de negociação", seja para que o Executivo conseguisse aprovação àquelas proposições consideradas prioritárias, seja para sinalizar à oposição o quanto estaria disposto a ceder ou não às pressões externas.

O acompanhamento da tramitação das proposições demonstrou que o processo decisório, pelo menos no campo da legislação social do trabalho, foi bem mais institucionalizado do que às vezes se assume. $\mathrm{O}$ Executivo conseguiu aprovar parte de sua agenda, não porque se valeu de poderes discricionários, mas porque houve uma clara articulação nas relações entre a Presidência e sua base parlamentar de apoio. No entanto, a cooperação foi, em grande medida, condicionada à área temática abordada pelas propostas. Dentre as matérias "não aprovadas", a maioria delas referia-se a temas vinculados ao Direito Coletivo de Trabalho - direito de greve, negociação coletiva etc. e principalmente organização sindical. Os diferentes resultados, no que se refere à legislação do Direito Coletivo e a do Direito Individual do Trabalho, decorrem da desigualdade dos recursos políticos que o governo destinou para sustentar essas propostas no Congresso.

O trâmite legislativo das proposições que tratam do Direito Coletivo se caracterizou pela não-utilização de mecanismos institucionais que facilitam a tramitação dos projetos e pela "permissão" à atuação dos partidos de oposição no processo decisório, diferentemente da tramitação das proposições relacionadas ao Direito Individual e ao Processual que se caracterizaram pela solicitação de pedidos de urgência, apreciação das matérias pelo plenário, apresentação de medidas provisórias, e alienação dos partidos de oposição. A apresentação de propostas via projeto de lei e sem a utilização dos pedidos de urgência sugere uma menor predisposição do governo e de sua base de sustentação em aprovar medidas que alterem a legislação que rege a estrutura sindical brasileira. 
Em resumo, embora não tenha ocorrido uma reforma profunda e radical da legislação do trabalho, vários aspectos dessa foram alterados, principalmente aqueles que regem os direitos individuais dos trabalhadores. A reforma da legislação sindical ficou para as próximas administrações.

(Recebido para publicação em março de 2005)

(Versão definitiva em junho de 2005)

\section{NOTAS}

1. Embora a tese central de Neustadt seja que o poder presidencial não é determinado pela estrutura formal - "'powers' are no guarantee of power" $\mathrm{e}$ "the probabilities of power do not derive from the literary theory of the Constitution" -, ele reconhece que o status constitucional oferece vantagens a partir das quais o presidente pode tentar persuadir os demais atores políticos (ver Neustadt, apud Edwards III, 2000).

2. Peterson (1993:40) assume que os presidentes têm seus objetivos prevalecentes e que incorporam na proposta suas próprias preferências, porém ocultando-as do conhecimento público e projetando somente aquelas posições que, segundo seus cálculos, levariam a resultados ótimos.

3. No Brasil, a permanência de um projeto em tramitação por tempo indeterminado só é possível aos projetos apresentados pelo Executivo. As proposições apresentadas pelo Legislativo que não tenham parecer de pelo menos uma das comissões, ao final da legislatura, são automaticamente arquivadas (artigo 105 do Regimento da Câmara).

4. A Convenção 87 foi encaminhada para apreciação do Congresso pelo presidente Dutra em 31/5/1949. Até 1980 não há registro do trâmite dessa convenção. Em 1984, o deputado Pedro Colin apresentou parecer favorável à aprovação (ver Diário do Congresso Nacional, 17/8/84).

5. Sobre as greves, ver Noronha (1994).

6. Organização sindical no que diz respeito ao sindicalismo do setor privado. Uma lei especial fixaria as regras para os servidores públicos (ver Exposição de Motivos do Ministro do Trabalho, Diário do Congresso Nacional, 19/6/87, p. 2054).

7. Ver jornais O Estado de S. Paulo, 25/11/2001 e de 16/12/2001; Folha de S. Paulo, de $18 / 3 / 2002$ e $20 / 4 / 2002$.

8. Quando o projeto foi posto em votação na Câmara, uma pane no painel eletrônico levou o então presidente da Casa, deputado Aécio Neves, a anular a votação. Embora o resultado indicasse vitória do governo, que tinha 49 votos a mais, o deputado Aécio Neves, ciente dos riscos de ser acusado de fraude em um embate político delicadíssi- 


\section{Simone Diniz}

mo preferiu adiar a votação. Em uma nova sessão, o projeto foi aprovado e encaminhado para apreciação do Senado (ver Revista Época, 3/12/2001).

9. Em entrevista ao jornal Folha de S. Paulo de 19/3/2002, o presidente Fernando Henrique deu a seguinte declaração: "a CPMF é necessária. Pode-se discutir se é boa ou má, não importa. Neste momento é preciso, porque o bolsa-escola, uma porção de ações de saúde e o equilíbrio fiscal dependem dela, então, eu diria que é um imperativo de consciência nacional".

10. A dificuldade de aprovação da CPMF não deve ser entendida como uma recusa a esse tributo. Todos os candidatos à Presidência sabiam da dependência do governo aos recursos gerados por aquela arrecadação. A relutância do PFL em apoiar a renovação tinha um sentido muito mais político. Era uma reação à operação da polícia federal na empresa Lunus, que inviabilizou a candidatura da governadora Roseana Sarney, pelo PFL (ver Folha de S. Paulo de 19/3/2002).

11. As principais reivindicações dos trabalhadores eram: reposição das perdas salariais; reajustes mensais; reintegração de 35 mil servidores demitidos desde 1985 e a retirada do Congresso das emendas de reforma constitucional (Martins e Rodrigues, 2000:158), dentre elas, a que tratava da questão do monopólio do petróleo.

12. Sobre as pretensões de reformas do presidente Collor ver discurso de posse (Diário do Congresso Nacional, 16/3/1990, p. 302).

13. A justificativa do governo para o uso de MP era que a contribuição deveria ser abolida antes da votação do novo orçamento da União, uma vez que $20 \%$ do valor arrecadado era destinado ao Ministério do Trabalho (Gomes e D'Araújo, 1993)

14. Em trabalho anterior fiz um levantamento da composição da CTASP entre 1989 e 1994. A indicação de parlamentares afinados com temas trabalhistas e sindicais foi feita a partir das notas atribuídas aos parlamentares pelo Departamento Intersindical de Assessoria Parlamentar - DIAP em "Quem é Quem na Constituinte" (ver Diniz, 1999).

15. A decisão do Tribunal Superior do Trabalho foi plenamente favorável ao governo, ao considerar que a greve era abusiva. De acordo com a Revista Veja, oㅜ 1.394 de 31/5/95, a decisão do TST já era conhecida pelo governo. Dias antes da greve, o ministro Almir Pazzianoto ligara para o ministro do Planejamento José Serra afirmando que os ministros estavam convencidos da ilegalidade da greve. Temiam, porém, que Fernando Henrique "amolecesse" do mesmo modo que Itamar o fizera em 1994. A resposta do presidente foi de que o governo não cederia às reivindicações dos grevistas.

16. A justificativa do presidente para a emissão da MP era a necessidade de "retirar do mercado de trabalho um mecanismo perverso, pelo qual a inflação passada era projetada no futuro, perpetuando assim, pela inércia, a elevação dos preços" (Cardoso, 1996). "O Mercado de Trabalho e a Geração de Empregos". Site da Presidência da República, Publicações.

17. O efeito suspensivo é uma espécie de liminar que permite a suspensão de decisões proferidas pelos Tribunais Regionais do Trabalho - TRTs a dissídios coletivos (ver www.tst.gov.br).

18. Embora a lei tenha previsto a participação dos sindicatos, Cacciamali (1999:227) informa-nos que "os acordos ocorrem, em muitos casos, diretamente entre empregados e patrões de uma empresa, sem a presença sindical, sem garantias legais de esta- 
bilidade para o grupo de trabalhadores que está negociando e sem o conhecimento, por parte destes, de informações contábeis, financeiras ou relativas ao desempenho da empresa".

\section{REFERÊNCIAS BIBLIOGRÁFICAS}

ALMEIDA, Maria Hermínia Tavares de. (1988), “Difícil Caminho: Sindicatos e Política na Construção da Democracia", in F. W. Reis e G. O'Donnell (orgs.), A Democracia no Brasil - Dilemas e Perspectivas. São Paulo, Vértice, pp. 327-367.

AMES, Barry. (2003), Entraves da Democracia no Brasil. Rio de Janeiro, Fundação Getulio Vargas Editora.

CACCIAMALI, Maria Cristina. (1999), “Desgaste na Legislação Laboral e Ajustamento do Mercado de Trabalho Brasileiro nos anos 90", in Abertura e Ajuste do Mercado de Trabalho - Politicas para Conciliar os Desafios de Emprego e Competitividade. Ministério do Trabalho, São Paulo, Editora 34.

CAMERON, Charles M. (2000), Veto Bargaining: Presidents and the Politics of Negative Power. Cambridge, Cambridge University Press.

CARDOSO, Fernando Henrique. (1996), O Impacto da Globalização nos Países em Desenvolvimento. Conferência pronunciada no Colégio do México, na Cidade do México, 20 de fevereiro.

CASTRO, Maria Silvia Portella de. (2001), As Mudanças nas Leis Trabalhistas e no Perfil Sindical no Brasil e na Argentina na Década de 90. Dissertação de Mestrado, Programa de Pós-Graduação em Integração da América Latina, USP.

COUTO, Cláudio Gonçalves. (2001), “O Avesso do Avesso - Conjuntura e Estrutura na Recente Agenda Política Brasileira". São Paulo em Perspectiva, vol. 15, nº 4.

DINIZ, Simone. (1999), "Processo Legislativo e Sistema de Comissões". Revista do Legislativo, no 26 , pp. 60-78.

EDWARDS III, George C. (2000), "Neustadt's Power Approach to the Presidency", in R. Y. Shapiro, M. J. Kumar e L. R. Jacobs (eds.), Presidential Power: Forging the Presidency for the Twenty-First Century. New York, Columbia University Press, pp. 9-15.

FIGUEIREDO, Argelina e LIMONGI, Fernando. (1999), Executivo e Legislativo na Nova Ordem Constitucional. Rio de Janeiro, Fundação Getulio Vargas Editora.

FREITAS, Carlos Eduardo Soares de. (2000), “Precarização e Flexibilização dos Direitos do Trabalho no Brasil doas anos 90". Dissertação de Mestrado, Departamento de Sociologia, UnB.

GOMES, Angela de Castro e D’ ARAÚJO, Maria Celina. (1993), “A Extinção do Imposto Sindical: Demandas e Contradições". Dados, vol. 36, no 2, pp. 317-352. 


\section{Simone Diniz}

JONES, Charles. (1994), The Presidency in a Separated System. Washington, D.C., The Brookings Institutions.

KELLER, Wilma Coelho de Souza. (1995), “Neocorporativismo e Relações de Trabalho: Considerações sobre a Experiência Brasileira Recente". Textos para Discussão, FUNDAP/IESP.

KREIN, José Dari e OLIVEIRA, Marco Antonio. (1999), “Mudanças Institucionais e Relações de Trabalho: As Iniciativas do Governo FHC no Período 1995-1998", in Anais do VI Encontro Nacional de Estudos do Trabalho, São Paulo, ABET, pp. 639-672, vol. I.

LOPES, Juarez Brandão. (1996), “Obstacles to Economic Reform in Brazil”, in A. Lijphart e C. H. Waisman (orgs.), Institutional Design in New Democracies - Eastern Europe and Latin America. Boulder, Westview Press.

MAINWARING, Scott e SHUGART, M. (1997), Presidentialism and Democracy in Latin America. New York, Cambridge University Press.

MARTINS, Heloísa de Souza e RODRIGUES, Iram Jácome. (2000), “O Sindicalismo Brasileiro na Segunda Metade dos Anos 90". Tempo Social, vol. 11, no 2, pp. 155-182.

MIAGUSKO, Edson. (2001), Greve dos Petroleiros de 1995: A Construção Democrática em Questão. Dissertação de Mestrado, Departamento de Sociologia, USP.

NEUSTADT, Richard. (1960), Presidential Power: The Politics of Leadership. New York, Wiley.

NORONHA, Eduardo Garuti. (1994), "Greves e Estratégias Sindicais no Brasil”, in C. A. de Oliveira, J. F. Siqueira Neto e M. A. Oliveira (orgs.), O Mundo do Trabalho - Crise e Mudança no Final do Século. São Paulo, Página Aberta.

OLIVEIRA, Marco Antonio. (2002), Política Trabalhista e Relações de Trabalho no Brasil - Da Era Vargas ao Governo FHC. Tese de Doutorado, Instituto de Economia, UNICAMP.

PESSANHA, Charles. (2001), "Poder Legislativo del Ejecutivo en Brasil: Decreto-Ley y Medida Provisoria, 1965-1999", in I. Cheresky e I. Pousadela (eds.), Politica e Instituciones en las Nuevas Democracias Latinoamericanas. Buenos Aires, Paidós Editorial, pp. 109-125.

PETERSON, Mark A. (1993), Legislating Together - The White House and Capitol Hill from Eisenhower to Reagan. Cambridge, MA, Harvard University Press.

RICCI, Paolo. (2001), As Relações de Poder entre Congresso e Executivo no Contexto Dinâmico do Decision-Making Brasileiro. Dissertação de Mestrado, USP.

RODRIGUES, Marta M. Assumpção e ZAULI, Eduardo Meira. (2002), "Presidentes e Congresso Nacional no Processo Decisório da Política de Saúde no Brasil Democrático (1985 a 1998)". Dados, vol. 45, no 3, pp. 387-429.

SANTOS, Fabiano. (1997). "Patronagem e Poder de Agenda na Política Brasileira". Dados, vol. 40, no 3, pp. 465-491.

SARTORI, Giovanni. (1996), Engenharia Constitucional: Como Mudam as Constituições. Brasília, Editora da UnB.

SHUGART, Mathew e CAREY, John. (1992), Presidents and Assemblies: Constitutional Design and Electoral Dynamics. New York, Cambridge University Press. 
LISTA DE SIGLAS DE PARTIDOS POLÍTICOS

PC do B - Partido Comunista do Brasil

PFL - Partido da Frente Liberal

PMDB - Partido do Movimento Democrático Brasileiro

PPB - Partido Progressista Brasileiro

PPS - Partido Popular Socialista

PSD - Partido Social Democrático

PSDB - Partido da Social Democracia Brasileira

PSL - Partido Social Liberal

Prona - Partido de Reedificação da Ordem Nacional

PT - Partido dos Trabalhadores

PDT - Partido Democrático Trabalhista

PTB - Partido Trabalhista Brasileiro 


\section{Simone Diniz}

Anexo 1

Propostas Apresentadas e Resultado da Tramitação

\begin{tabular}{|c|c|c|c|}
\hline TNJR & RTPA & TRAM & VETO TOTAL \\
\hline & $\begin{array}{l}\text { Governo Sarney } \\
\text { PL 164/87 } \\
\text { organização sindical }\end{array}$ & & \\
\hline & $\begin{array}{l}\text { Governo Collor } \\
\text { PL 1.231/91 } \\
\text { organização sindical } \\
\text { PL 1.232/91 } \\
\text { negociação coletiva }\end{array}$ & & $\begin{array}{l}\text { Governo Collor } \\
\text { MP } 215 / 90 \\
\text { PLV } 58 \\
\text { imposto sindical }\end{array}$ \\
\hline $\begin{array}{l}\text { Governo Itamar } \\
\text { MP 794/94 } \\
\text { Participação nos lucros }\end{array}$ & $\begin{array}{l}\text { Governo Itamar } \\
\text { PL } 4.768 / 94 \\
\text { Comissão de conciliação }\end{array}$ & & \\
\hline $\begin{array}{l}\text { Governo Fernando } \\
\text { Henrique(I) } \\
\text { PL 4.693/98 (Lei 9.957) } \\
\text { Rito sumaríssimo }\end{array}$ & $\begin{array}{l}\text { Governo Fernando } \\
\text { Henrique (I) } \\
\text { PL } 4.893 / 95 \\
\text { processo de trabalho }\end{array}$ & $\begin{array}{l}\text { Governo Fernando } \\
\text { Henrique(I) } \\
\text { PL } 3.003 / 97 \\
\text { contribuição negocial } \\
\text { do sistema confederati- } \\
\text { vo } \\
\text { PL } 1.802 / 96 \\
\text { direito de greve } \\
\text { PL } 4.302 / 98 \\
\text { Trabalho. temporário } \\
\text { PL 3.748/97 } \\
\text { rescisão contratual }\end{array}$ & \\
\hline $\begin{array}{l}\text { PL 4.694 / } 98 \text { (Lei 9.958) } \\
\text { Comissão de conciliação }\end{array}$ & & & \\
\hline $\begin{array}{l}\text { PL } 1.724 \text { / } 96 \\
\text { banco de horas / contrata- } \\
\text { ção por tempo determi- } \\
\text { nado }\end{array}$ & & & \\
\hline $\begin{array}{l}\text { MP } 1.053 / 95 \\
\text { livre negociação } \\
\text { MP 1.709/98 (Lei 10.101) } \\
\text { banco de horas }\end{array}$ & & & \\
\hline $\begin{array}{l}\text { MP 1.070/95 (Lei 9.491) } \\
\text { efeito suspensivo/utili- } \\
\text { zação recursos FGTS }\end{array}$ & & & \\
\hline $\begin{array}{l}\text { MP } 1.523 / 96 \text { (Lei } \\
\text { rescisão contratual }\end{array}$ & & & \\
\hline $\begin{array}{l}\text { Governo Fernando Hen- } \\
\text { rique (II) } \\
\text { Reedições das MPs }\end{array}$ & $\begin{array}{l}\text { Governo Fernando } \\
\text { Henrique (II) } \\
\text { PL 5.483/01 } \\
\text { prevalência do negocia- } \\
\text { do sobre o legislado }\end{array}$ & & \\
\hline
\end{tabular}

TNJR = Transformado em Norma Jurídica

RTPA = Retirado pelo Autor

TRAM = Em Tramitação 


\begin{abstract}
Interaction between the Executive and Legislative Branches in the Decision-Making Process: Evaluation of Presidential Success and Failure

This article discusses how to evaluate success and failure in the approval of a given government agenda. Through an analysis of labor legislation reform bills submitted by the Brazilian Executive Branch from 1989 to 2001, the article shows that the success or failure of the Administration's agenda cannot be measured only by the bill's final review. The attempt was to demonstrate how submitting bills is part of a broader strategy, extending beyond the specific bill, and that passing bills is not necessarily the main objective of those submitting them.
\end{abstract}

Key words: Presidential success and failure; government agenda; labor reform

\title{
RÉSUMÉ
}

Interactions entre les Pouvoirs Exécutif et Législatif dans le Processus de Décision: Bilan du Succès et de l'Échec Présidentiel

Dans cet article, on analyse la façon d'évaluer le succès et l'échec dans l'adoption d'un calendrier de mesures gouvernementales. Par l'analyse des propositions de réforme de la législation du travail présentées par le pouvoir exécutif entre 1989 et 2001, on vérifie que le succès et l'échec du programme présidentiel ne dépend pas seulement de l'acheminement final de sa proposition. On a essayé de montrer que la présentation des projets fait partie d'une stratégie plus large, qui dépasse le projet envoyé, et que l'acceptation d'un projet n'est toujours pas le principal objectif de celui même qui le propose.

Mots-clé: succès et échec présidentiel; calendrier de mesures gouvernementales; réforme de la législation du travail 